\title{
PENGARUH KOMPETENSI FASILITATOR DAN HASIL BELAJAR PESERTA PELATIHAN KELUARGA SEHAT
}

\author{
Yunia Saputri, Lasi Purwito, Edi Widianto \\ Jurusan Pendidikan Luar Sekolah \\ Fakultas Ilmu Pendidikan \\ Universitas Negeri Malang, Jl. Semarang No. 05 Malang \\ E-mail: eviyuniasaputri@gmail.com
}

\begin{abstract}
Abstrack: The objectives of the study were: (1) to determine the effect of facilitator competency on the learning outcomes of healthy family training participants, (2) to determine the effect of learning motivation on learning outcomes of healthy family trainees, (3) to determine the effect of facilitator competence and learning motivation on participants' learning outcomes healthy family training. The results showed that the Facilitator Competence had a significance value (Sig.) 0.044 in the Coefficientsa table with a value of a (degree of significance) 0.05 meaning $0.044<0.05$ or there was a significant effect and the test showed 2.112> ttable (2.052). This means that Facilitator Competence has a significant effect on learning outcomes, and Learning Motivation has a significance value (Sig.) 0.009 in the Coefficientsa table with a value of a (degree of significance) 0.05 meaning $0.009<0.05$ or there is a significant effect of the test showing 2.817> ttable (2.052) This means that Learning Motivation has a significant effect on Learning Outcomes. Thus simultaneously the Competency variables of the Facilitator and Learning Motivation variables have a positive and significant influence on Learning Outcomes.
\end{abstract}

\section{Keywords: Facilitator Competence, Learning Motivation, Learning Outcomes}

Abstrak: Tujuan penelitian: (1) untuk mengetahui pengaruh kompetensi fasilitator terhadap hasil belajar peserta pelatihan keluarga sehat, (2) untuk mengetahui pengaruh motivasi belajar terhadap hasil belajar peserta pelatihan keluarga sehat, (3) untuk mengetahui pengaruh kompetensi fasilitator dan motivasi belajar terhadap hasil belajar peserta pelatihan keluarga sehat. Hasil penelitian menunjukkan bahwa Kompetensi Fasilitator memiliki nilai signifikansi (Sig.) 0.044 pada tabel Coefficients ${ }^{\mathrm{a}}$ dengan nilai $\alpha$ (derajat signifikansi) 0.05 artinya $0.044<0.05$ atau terdapat pengaruh yang signifikan dan uji $t$ menunjukkan 2.112> $t_{\text {tabel }}$ (2.052). Artinya Kompetensi Fasilitator berpengaruh signifikan terhadap hasil belajar, dan pada Motivasi Belajar memiliki nilai

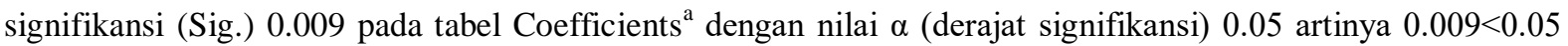
atau terdapat pengaruh yang signifikan dari uji $\mathrm{t}$ menunjukkan 2.817> $\mathrm{t}_{\text {tabel }}$ (2.052). Artinya Motivasi Belajar berpengaruh signifikan terhadap Hasil Belajar. Dengan demikian secara simultan variabel Kompetensi Fasilitator dan variabel Motivasi Belajar memiliki pengaruh positif dan signifikan terhadap Hasil Belajar.

\section{Kata Kunci: Kompetensi Fasilitator, Motivasi Belajar, Hasil Belajar}

\section{PENDAHULUAN}

Menurut UU No. 20 Tahun 2003 tentang Sistem Pendidikan Nasional pasal 1 "Pendidikan yaitu usaha sadar dan terencana dalam mewujudkan suasana belajar dan proses pembelajaran agar peserta didik secara aktif mengembangkan potensi diri, kecerdasan, kepribadian, akhlak mulia, serta keterampilan yang diperlukan dirinya, masyarakat, bangsa dan Negara." Pendidikan sangat penting, karena tanpa pendidikan manusia akan sulit berkembang dan bahkan akan terbelakang. Dengan demikian pendidikan harus betul-betul diarahkan untuk dapat menghasilkan sumber daya manusia yang mampu bersaing dan berkualitas. Jalur pendidikan di Indonesia terdapat tiga (3) jalur antara lain pendidikan formal, pendidikan

nonformal, dan pendidikan informal. Pendidikan formal merupakan pendidikan yang terstruktur dan berjenjang. Sedangkan pendidikan nonformal merupakan semua pendidikan yang berada diluar sistem pendidikan formal. Menurut UU No. 20 tahun 2003 pasal 26 "Satuan pendidikan nonformal terdiri atas lembaga 
kursus, lembaga pelatihan, kelompok belajar, pusat kegiatan belajar masyarakat, dan majelis taklim, serta satuan pendidikan yang sejenis."

Pelaksanaan pelatihan harus dikelola sebaik mungkin karena akan berpengaruh terhadap keberhasilan suatu pelatihan. Keberhasilan suatu pelatihan dapat dilihat dari hasil belajar peserta pelatihan. Hasil belajar menurut Sudjana (2009:3) pada hakikatnya adalah "perubahan tingkah laku sebagai hasil belajar yang mencakup bidang kognitif, afektif, psikomotorik." Dengan demikian hasil belajar dari pelatihan adalah bentuk peningkatan kompetensi yang ditunjukkan dari berbagai segi baik kognitif (pengetahuan), afektif (keterampilan), dan psikomotorik (sikap) peserta serta mampu meningkatkan kreativitas dan inovasi dalam menghasilkan ide-ide kreatif untuk kemajuan diri peserta pelatihan dan sesuai tujuan organisasi.

Hasil belajar adalah salah satu tolak ukur suatu keberhasilan peserta didik dalam mempelajari materi yang disampaikan selama periode atau waktu tertentu, untuk dapat mengetahui hasil belajar peserta didik, fasilitator perlu mengadakan evaluasi atas kemampuan peserta didik saat memahami materi yang telah disampaikan atau diberikan melalui hasil evaluasi tersebut, maka dapat diketahui hasil belajar yang didapat peserta didik. Menurut Winarno (2014:7) "dalam setiap kegiatan, selalu akan ada hasil yang ingin dicapai, begitu pula dengan kegiatan memberikan pendidikan (mendidik)." Hasil akhir yang ingin dicapai oleh pendidikan adalah bagaimana dapat menghasilkan manusia-manusia terdidik yang sesuai dengan tujuan atau kurikulum yang ditetapkan. Hasil belajar adalah perubahan perilaku yang diperoleh peserta didik setelah melaksanakan kegiatan belajar atau pembelajaran. Maka dari itu hasil belajar merupakan hal yang penting dalam pendidikan karena dapat mengetahui bahwa tujuan pendidikan sudah tercapai atau belum secara optimal, dalam hubungannya dengan tingkatan pada dunia pendidikan, tujuannya, yaitu (a) Tujuan Universal, (b) Tujuan Nasional, (c) Tujuan Institusional, (d) Tujuan Kurikuler, (e) Tujuan Instruktusional.

Salah satu faktor yang mempengaruhi hasil belajar peserta didik adalah fasilitator. Dalam proses kegiatan belajar-mengajar terjadi interaksi antara pendidik dan peserta didik yang outpunya salah satunya adalah hasil belajar. Hasil belajar dipengaruhi oleh dua faktor yaitu (a) faktor internal adalah faktor yang berasal dari dalam diri peserta didik, antara lain kecerdasan, faktor fisiologis, sikap, minat, bakat, motivasi, (b) faktor eksternal adalah faktor yang mempengaruhi berasal dari luar diri peserta didik, antaraa lain latar belakang keluarga, sekolah, masyaralat. Faktor ekternal yang mempengaruhi hasil belajar salah satunya adalah fasilitator. Fasilitator dan peserta didik adalah dua komponen yang tidak dapat dipisahkan dari dunia pendidikan karena fasilitator bertugas mendidik setiap peserta didik menjadi lebih produktif. Selain itu, fasilitator juga memiliki peranan yang sangat penting yaitu memegang pendidikan dan pengajaran di dalam sebuah kegiatan pelatihan sehingga dapat menjadi salah satu faktor penentu keberhasilan peserta didik. Dalam penelitian ini penulis hanya akan membahas faktor eksternal yaitu kompetensi fasilitator dalam mendidik, melatih proses belajar-mengajar dan faktor internal yaitu motivasi belajar peserta didik.

Dunia pendidikan sekarang berkembang sangat pesat. Semakin kompleksnya permasalahan pendidikan yang dihadapi bukanlah tantangan yang dibiarkan begitu saja, tetapi perlu adanya solusi untuk menyelesaikannya, untuk mendapatkan kualitas pendidikan yang lebih baik. Persoalan yang dimaksud diantaranya adalah kompetensi fasilitator dalam kegiatan mengajar, mendidik, melatih. Karena fasilitator sebagai tenaga pendidik yang paling banyak berinteraksi 
dengan peserta didik, jadi diharapakan memiliki kompetensi yang baik dalam kegiatan belajar-mengajar. Oleh karena itu, syarat menjadi fasilitator harus memiliki berbagai kompetensi dalam melaksanakan tugas keprofesionalnya.

Pendidikan yang ideal haruslah mampu mengembangkan potensi diri seseorang baik sebagai makhluk individu maupun makhluk sosial dengan mengembangkan potensi cipta, rasa, dan karsanya. Tujuan dari proses pembelajaran bahwa semua peserta didik dapat memperoleh hasil belajar yang memuaskan. Peraturan Menteri Pendidikan Nasional No. 16 Tahun 2007 menjelaskan bahwa "setiap pendidik wajib memenuhi standar kualifikasi akademik dan kompetensi pendidik sesui dengan peraturan pendidikan nasional." Standar kompetensi pendidik yang harus dipenuhi oleh pendidik ada empat kompetensi, yaitu (a) Kompetensi Pedagogik, Kompetensi Kepribadian, (c) Kompetensi Sosial, (d) Kompetensi Profesional. Kompetensi yang berhubungan serta dengan pendidik sebagai sebuah profesi adalah kompetensi professional. Selain kompetensi pendidik, motivasi belajar peserta didik juga sangat berperan penting dalam pencapain hasil belajar. Menurut Dimyati dan Mudjiono (2006:80) motivasi merupakan "dorongan mental yang menggerakkan dan mengarahkan perilaku manusia, termasuk perilaku belajar." Dalam motivasi terkandung adanya keinginan yang mengaktifkan, menggerakkan, menyalurkan, dan mengarahkan sikap dan individu belajar.

Kuat lemahnya motivasi belajar juga mempengaruhi hasil belajar yang diperoleh peserta didik dalam kegiatan pembelajaran. Oleh karena itu, motivasi belajar perlu diusahakan, terutama motivasi yang berasal dalam diri untuk mencapai tujuan lebih baik dalam pendidikan.

Motivasi dalam belajar sangatlah penting, karena mempengaruhi peserta didik untuk emlakukan kegiatan belajar.
Persoalan terkait dengan motivasi dalam belajar adalah bagaimana agar suatu motivasi itu dapat meningkat. Dalam memberikan motivasi, pendidik/fasilitator harus berusaha untuk mengarahkan perhatian peserta didik pada sasaran tertentu. Dengan adanya dorongan dalam diri peserta didik maka akan meningkatkan motivasi belajar.

Berkualitas atau tidaknya suatu tempat pendidikan tentu tidak dapat dipisahkan dengan peranan dari berbagai pihak terkait. Ukuran kualitas pendidikan didasarkan pada standar hasil yang telah ditentukan secara bersama sesuai dengan level, jenjang, dan jenis pendidikan. Kualitas pada konteks ini merupakan hasil dari proses yang panjang dan sangat kompleks karena faktor yang terdapat di dalamnya sangat komples seperti tenaga pendidik, kurikulum, sarana dan prasarana, pengelolaan, warga belajar, sumber belajar, dan evaluasi.

\section{METODE}

Menurut Sugiyono (2016:2) "metode penelitian pada dasarnya merupakan cara ilmiah untuk mendapatkan data dengan tujuan dan kegunaan tertentu." Pada penelitian ini, peneliti akan menganalisis mengenai Pengaruh Kompetensi dan Motivasi Belajar Terhadap Hasil Belajar Peserta Pelatihan Keluarga Sehat Angkatan VII di UPT Pelatihan Kesehatan Masyarakat Murnajati, sehingga pendekatan dalam penelitian ini adalah pendekatan kuantitatif. Metode penelitian yang digunakan adalah metode penelitian deskripsif dengan analisis regresi berganda. Metode penelitian deskriptif menurut Sugiyono (2016:100) "adalah penelitian yang digunakan untuk menganalisis data dengan cara mendeskripsikan atau menggambarkan data yang telah terkumpul." Sedangkan studi regresi berganda menurut Arikunto (2014:201) "analisis regresi berganda digunakan untuk mengetahui pengaruh atau hubungan linier antara dua atau lebih 
variabel independen dengan satu variabel dependen."

Dengan metode penelitian yang sudah ditentukan ini peneliti bermaksud untuk mengumpulkan data historis dan mengamati secara seksama mengenai aspek-aspek tertentu yang berkaitan dengan permasalahan yang sedang diteliti sehingga peneliti akan memperoleh datadata yang mendukung untuk penyusunan laporan penelitian. Data-data yang sudah diperoleh tersebut oleh peneliti kemudian akan diproses serta dianalisis lebih lanjut berdasarkan dasar teori yang telah dipelajari sehingga dapat memperoleh gambaran mengenai objek yang sedang diteliti dan selanjutnya akan ditarik kesimpulan mengenai masalah yang diteliti. Adapun variabel dalam penelitian ini dibedakan menjadi dua yaitu variabel bebas (X1, X2) dan variabel terikat (Y).

Menurut Sugiyono (2016:80) populasi adalah "wilayah generalisasi yang terdiri atas obyek atau subyek yang mempunyai kualitas dan karakteristik tertentu yang ditetapkan oleh peneliti untuk dipelajari dan kemudian ditarik kesimpulannya." Populasi yang digunakan dalam penelitian ini adalah peserta pelatihan keluarga sehat angkatan VII di UPT Pelatihan Kesehatan Masyarakat Murnajati. Berdasarkan hasil observasi diperoleh jumlah populasi sebanyak 30 orang.

Menurut Sugiyono (2016:81) sampel adalah "bagian dari jumlah dan karakteristik yang dimiliki oleh populasi tersebut." Dalam penelitian ini sampel yang digunakan adalah sampel jenuh, yaitu menggunakan populasi yang ada. Menurut Sangadji (2010:189), "sampling jenuh adalah teknik penentuan sampel bila semua anggota populasi sebagai sampel." Dalam penelitian ini sampel yang digunakan adalah seluruh peserta yang mengikuti pelatihan keluarga sehat VII di UPT Pelatihan Kesehatan Masyarakat Murnajati Lawang sebanyak 30 orang.

Teknik dalam penelitian ini adalah menggunakan angket dan dokumentasi.
Menurut Sugiyono (2016:142) menjelaskan kuisioner atau angket adalah "teknik pengumpulan data yang dilakukan dengan cara memberi seperangkat pertanyaan atau pernyataan tertulis kepada responden untuk dijawabnya. Skala pengukuran angket ini menggunakan skala Likert. Menurut Arikunto (2013:201) metode dokumentasi "dapat berbentuk tulisan, gambar, atau karya-karya monumental dari seseorang." Pengambilan data dokumentasi dapat berupa tulisan (paper), tempat (place), dan kertas atau orang (people). Dalam penelitian ini dokumentasi yang digunakan adalah data nilai hasil belajar dan data nama peserta pelatihan keluarga sehat angkatan VII di UPT Pelatihan Kesehatan Masyarakat Murnajati. Dokumentasi pendukung lainnya disajikan berupa foto yang diperoleh saat penelitian dilaksanakan.

Intrumen yang digunakan untuk mengukur pengaruh kompetensi fasilitator dan motivasi belajar terhadap hasil belajar yaitu butir-butir pertanyaan maupun pernyataan dalam angket akan dikembangkan berdasarkan teori yang relevan dengan masing-masing variabel penelitian. Angket yang dibuat akan diukur menggunakan skala Likert. Sehingga setiap responden harus memilih satu diantara 5 alternatif jawaban yang ada dari masing-masing item, tidak ada jawaban benar atau salah, setiap jawaban akan mempunyai skor yang berbeda.

Penyusunan instrument dalam bentuk angket dilakukan dalam beberapa tahap meliputi: (1) menentukan indikatorindikator untuk setiap

variabel penelitian, (2) menentukan sub indikator dari setiap indikator, dan (3) membuat butir-butir pertanyaan.

\section{Uji Coba Instrumen}

Sebelum digunakan dalam penelitian, perlu dilakukan uji instrumen agar instrumen yang digunakan dapat dikatakan benar-benar baik. Menurut Sugiyono (2016:121), "instrumen yang baik harus memenuhi dua persyaratan penting yaitu 
valid dan reliable". Dengan demikian, suatu instrumen penelitian harus melalui serangkaian uji validitas dan uji reabilitas untuk menghasilkan penelitian yang valid dan reliable. Hasil penelitian yang valid bila terdapat kesamaan antara data yang terkumpul dengan data yang sesungguhnya terjadi pada obyek yang diteliti (Sugiyono 2016:121). Uji validitas dalam penelitian ini dilakukan terhadap 15 responden.

Dalam uji validitas instrumen motivasi belajar didapatkan hasil uji 23 butir instrument atau pertanyaan dinyatakan valid, sedangkan 3 instrumen dinyatakan tidak valid. Hasil penelitian yang reliabel, bila terdapat kesamaan data dalam waktu yang berbeda (Sugiyono 2016:121). Instrumen yang reliabel adalah instrumen yang bila digunakan beberapa kali untuk mengukur obyek yang sama, akan menghasilkan data yang sama. Reliabilitas juga sama dengan konsistensi atau keajekan. Pada penelitian ini suatu instrument memiliki nilai reliabilitas yang tinggi apabila instrumen yang dibuat mempunyai hasil yang konsisten dalam mengukur apa yang hendak diukur.

\section{Teknik Analisis Data}

Teknik analisis data sesuai dengan tujuan penelitian yaitu mengetahui tentang pengaruh kompetensi fasilitator dan motivasi belajar terhadap hasil belajar peserta pelatihan keluarga sehat angkatan VII di UPT Pelatihan Kesehatan Masyarakat Murnajati. Menurut Sugiyono (2016:147) analisis data merupakan kegiatan setelah data dari seluruh responden telah terkumpul. Kegiatan yang dilakukan didalam analisis data adalah mengelompokkan data berdasarkan pada variabel dan jenis responden, mentabulasi data berdasarkan variabel dan seluruh responden, menyajikan data dari setiap variabel yang diteliti, melakukan perhitungan untuk menjawab rumusan masalah dan melakukan perhitungan untuk menguji hipotesis yang telah diajukan. Teknik analisis data antara lain (1) pemeriksaan (editing), Tahapan pemeriksaan (editing) merupakan kegiatan yang dilakukan oleh peneliti setelah peneliti mendapat data yang berasal dari lapangan. Pada tahapan ini peneliti memeriksa data yang telah terkumpul dengan tujuan agar tidak ada data yang terlewatkan. Pelaksanaan kegiatan ini dimulai dengan memberikan identitas pada instrument yang telah diisi oleh responden yang selanjutnya diperiksa satu persatu. Kemudian diperiksa juga poin-poin serta jawaban yang telah tersedia. (2) pemberian identitas (coding), Tahap pemberian identitas (coding) bertujuan untuk mempermudah peneliti dalam proses tabulasi data. Pada tahapan ini peneliti memberikan kode angka sesuai dengan skala angka yang telah ditentukan dalam alternatif jawaban yang disediakan, (3) pembeberan (tabulating), Tahap tabulasi merupakan tahapan ke tiga dalam kegiatan analisis data. Pada tahap ini peneliti berusaha untuk membeberkan data yang telah diperoleh dalam penelitian. Tahap pembeberan dilakukan dengan memasukkan data pada tabel-tabel yang telah dibuat untuk mengukur angka yang kemudian akan dihitung. Proses pembeberan atau tabulasi ini dilkasanakan dengan menggunakan program computer yaitu Microsoft Excel. (4) analisis statistic,

Dalam penelitian kuantitatif, analisis data merupakan kegiatan setelah data dari seluruh responden atau sumber data lain terkumpul. Kegiatan dalam analisis data adalah: mengelompokkan data berdasarkan variabel dan jenis responden, mentabulasi data berdasarkan variabel dari seluruh responden, menyajikan data tiap variabel yang diteliti, melakukan perhitungan untuk menjawab rumusan masalah, dan melakukan perhitungan untuk menguji hipotesis yang telah diajukan. Untuk penelitian yang tidak merumuskan hipotesis, langkah terakhir tidak dilakukan.

\section{HASIL}

Pelaksanaan pengisian kuesioner atau angket dilakukan peneliti sebelum dilakukan pembelajaran sehingga tidak 
mengganggu proses pembelajaran dalam pelatihan Keluarga Sehat Angkatan VII di UPT Pelatihan Kesehatan Masyarakat Murnajati. Peserta diminta untuk memberikan check-list disetiap jawaban di dalam kolom yang sudah disediakan oleh peneliti sesuai dengan kenyataan dilapangan. Pengisian angket angket kuesioner dilakukan sesudah peneliti membacakan petunjuk pengisian dan waktu pengisian yaitu 15-20 menit. Kuesioner atau angket yang disebarkan ke peserta pelatihan berjumlah 30 angkat dan terdiri dari 32 item pertanyaan untuk variabel kompetensi fasilitator serta 23 item pernyataan untuk variabel motivasi belajar.

\section{a. Karakteristik Responden Berdasarkan Jenis Kelamin}

Responden yang diambil dalam penelitian ini dengan karakteristik berdasarkan jenis kelamin.

Diketahui bahwa jumlah responden dalam penelitian ini berjumlah 30 peserta pelatihan yang terdiri dari 7 laki-laki atau $(23 \%)$ dan 23 orang perempuan atau (77\%). Berdasarkan kategori tersebut responden sebagian besar adalah perempuan yaitu sebanyak 23 orang atau $77 \%$. Peserta pelatihan keluarga sehat angkatan VII ini sebagian besar merupakan pegawai puskesmas yang berprofesi sebagai perawat dan bidan, sehingga dalam hal ini berpengaruh terhadap banyaknya peserta pelatihan yang berjenis kelamin perempuan dibanding laki-laki.

\section{b. Karakteristik Responden Berdasarkan Usia}

Responden dalam penelitian berdasarkan usia dibagi menjadi 6 kategori usia.

Diketahui bahwa responden yang memiliki usia $<20$ tahun berjumlah 0 orang atau dengan persentase sebesar $0 \%$, usia 20-30 tahun berjumlah 8 orang atau dengan persentase sebesar $27 \%$, usia $31-40$ tahun berjumlah 13 orang atau dengan persentase 43\%, usia 41-50 tahun berjumlah 7 orang atau dengan persentase 23\%, usia 51-60 tahun berjumlah 2 orang atau dengan persentase $7 \%$ dan usia $>60$ tahun berjumlah 0 orang atau dengan persentase $0 \%$. Berdasarkan kategori tersebut responden sebagian besar memiliki usia 31-40 tahun yaitu sebanyak 13 orang atau $43 \%$, dalam usia tersebut merupakan usia produktif seseorang dimana usia seseorang masih mampu bekerja dan menghasilkan sesuatu.

\section{c. Karakteristik Responden Berdasarkan Pendidikan}

Responden dalam penelitian berdasarkan pendidikan dibagi menjadi 10 kategori.

Diketahui bahwa responden yang pendidikan SMP/MTS/PAKET sebanyak 0 orang atau $0 \%$, pendidikan SMA/SMK/MA/PAKET sebanyak 0 orang atau $0 \%$, pendidikan D1 sebanyak 0 orang atau $0 \%$, pendidikan D2 sebanyak 0 orang atau $0 \%$, pendidikan D2 sebanyak 0 orang atau $0 \%$, pendidikan D3 sebanyak 23 orang atau $77 \%$, pendidikan D4 sebanyak 1 orang atau $3 \%$, pendidikan S1 sebanyak 6 orang atau 20\%, pendidikan S2 sebanyak 0 orang atau $0 \%$, pendidikan S3 sebanyak 0 orang atau $0 \%$, dan pendidikan lainnya sebanyak 0 orang atau $0 \%$. Berdasarkan kategori tersebut responden sebagian besar berpendidikan D3 yaitu 23 orang atau $77 \%$. Pendidikan terakhir yang ditempuh peserta pelatihan ini adalah mayoritas D3 keperawatan dan kebidanan, karena peserta pelatihan disini sebagian besar merupakan pegawai puskesmas dimana perawat dan bidan merupakan tenaga kesehatan yang sangat dibutuhkan.

\section{d. Karakteristik Responden Berdasarkan Frekuensi Mengikuti Pelatihan di UPT Latkesmas Murnajati}


Responden dalam penelitian berdasarkan frekuensi mengikuti pelatihan di UPT Latkesmas Murnajati di bagi menjadi 5 kategori. Adapun persebaran responden berdasarkan frekuensi mengikuti pelatihan di UPT Latkesmas Murnajati dapat dilihat pada tabel berikut:

Tabel 1 Karakteristik Berdasarkan Frekuensi Mengikuti Pelatihan di UPT Latkesmas Murnajati

\begin{tabular}{lll}
\hline $\begin{array}{l}\text { Mengikuti } \\
\text { Pelatihan }\end{array}$ & Jumlah & Persentase \\
\hline 1 kali & 20 & $67 \%$ \\
\hline 2 kali & 6 & $20 \%$ \\
\hline 3 kali & 2 & $7 \%$ \\
\hline 4 kali & 1 & $3 \%$ \\
\hline Lainnya & 1 & $3 \%$
\end{tabular}

(Sumber: data primer diolah: 2019)

Berdasarkan tabel diketahui bahwa frekuensi responden mengikuti pelatihan di UPT Latkesmas Murnajati yaitu kategori pertama sebanyak 1 kali ada 20 orang atau $67 \%$, kategori kedua sebanyak 2 kali ada 6 orang atau 20\%, kategori ketika sebanyak 3 kali ada 2 orang atau $7 \%$, kategori keempat sebanyak 4 kali ada 1 orang atau 3\%, kategori kelima lainnya sebanyak 1 orang atau 3\%. Berdasarkan kategori tersebut responden sebagian besar mengikuti pelatihan di UPT Latkesmas Murnajati sebanyak 1 kali yaitu 20 orang atau $67 \%$. Sebagian besar peserta pelatihan berasal dari daerah Tuban, Jombang, sehingga jarak yang jauh menjadi salah satu penyebab mereka baru pertama kali mengikuti pelatihan di UTP Pelatihan Kesehatan Masyarakat Murnajati.

\section{Analisis Deskriptif}

Analisis deskriptif digunakan untuk menggambarkan kondisi masing-masing variabel penelitian, yaitu kompetensi fasilitator (X1), motivasi belajar (X2), dan hasil belajar (Y) sebagai variabel terikat. Penelitian ini dilakukan pada peserta pelatihan keluarga sehat angkatan VII di UPT Pelatihan Kesehatan Masyarakat Murnajati. Berikut ini adalah deskriptif data dari masaing-masing variabel:

\section{Deskripsi Variabel Kompetensi Fasilitator (X1)}

Variabel motivasi belajar memiliki 32 pertanyaan kompetensi fasilitator. Dari 32 pertanyaan tersebut, terdapat nilai mean yang tertinggi yaitu 4.93 yaitu dengan pertanyaan "apakah dalam proses memfasilitasi pelatihan fasilitator memanfaatkan teknologi informasi (laptop, komputer)". Sedangkan nilai terendah adalah 3.43 yaitu dengan pertanyaan "apakah fasilitator bersifat tegas pada saat peserta pelatihan melakukan pelanggaran".

Tabel 2 Kategori Nilai Variabel

Kompetensi Fasilitator

\begin{tabular}{llll}
\hline Interval & Kriteria & $\begin{array}{l}\text { Fre } \\
\text { kue } \\
\text { nsi }\end{array}$ & $\begin{array}{l}\text { Persenta } \\
\text { se }\end{array}$ \\
\hline $140-166$ & Selalu & 19 & $63.3 \%$ \\
\hline $113-139$ & Sering & 11 & $36.7 \%$ \\
\hline $86-112$ & $\begin{array}{l}\text { Kadang- } \\
\text { kadang }\end{array}$ & 0 & $0 \%$ \\
\hline $59-85$ & Pernah & 0 & $0 \%$ \\
\hline $32-58$ & $\begin{array}{l}\text { Tidak } \\
\text { pernah }\end{array}$ & 0 & $0 \%$ \\
\hline
\end{tabular}

(Sumber: data primer diolah: 2019)

Berdasarkan penjelasan tabel 2 dapat diketahui bahwa besarnya kompetensi fasilitator pada pelatihan keluarga sehat VII di UPT Pelatihan Kesehatan Masyarakat Murnajati adalah 0 peserta pelatihan keluarga sehat angkatan VII persentasenya $0 \%$ dengan klasifikasi tidak pernah, 0 peserta pelatihan keluarga sehat angkatan VII persentasenya $0 \%$ dengan klasifikasi pernah, 0 peserta pelatihan keluarga sehat angkatan VII persentasenya $0 \%$ dengan klasifikasi kadang-kadang, 11 peserta pelatihan keluarga sehat angkatan VII persentasenya $36,7 \%$ dengan klasifikasi sering, 19 peserta pelatihan keluarga sehat angkatan VII persentasenya $63,3 \%$ dengan klasifikasi selalu.

Sesuai dengan penjabaran di atas dapat disimpulkan bahwa kompetensi fasilitator pada pelatihan keluarga sehat angkatan VII tergolong sangat tinggi yaitu dibuktikan sebanyak 19 peserta pelatihan 
keluarga sehat angkatan VII dengan persentase sebesar $63,3 \%$ menunjukkan pada klasifikasi selalu. Dengan persentase yang tergolong tinggi tersebut, maka dalam hal ini dapat dikatakan bahwa kompetensi fasilitator (X1) berpengaruh terhadap hasil belajar peserta pelatihan keluarga sehat angkatanVII.

Variabel motivasi belajar memiliki 23 pernyataan motivasi belajar. Dari 23 pernyataan tersebut, terdapat nilai mean yang tertinggi yaitu 4.77 yaitu dengan pernyataan "saya mengikuti pelatihan karena ada surat tugas dari dinas". Sedangkan nilai terendah adalah 2.60 yaitu dengan pernyataan "saya mengikuti pelatihan karena kemauan saya sendiri”.

\section{Tabel 3 Kategori Nilai Variabel}

\section{Motivasi Belajar}

\begin{tabular}{llll}
\hline Interval & Kriteria & F & Presentase \\
\hline $99-117$ & Selalu & 6 & $20 \%$ \\
\hline $80-98$ & Sering & 21 & $70 \%$ \\
\hline $61-79$ & $\begin{array}{l}\text { Kadang- } \\
\text { kadang }\end{array}$ & 3 & $10 \%$ \\
\hline $42-60$ & Pernah & 0 & $0 \%$ \\
\hline $23-41$ & $\begin{array}{l}\text { Tidak } \\
\text { pernah }\end{array}$ & 0 & $0 \%$ \\
\hline
\end{tabular}

(Sumber: data primer diolah: 2019)

Berdasarkan penjelasan tabel di atas dapat diketahui bahwa besarnya motivasi belajar pada pelatihan keluarga sehat VII di UPT Pelatihan Kesehatan Masyarakat Murnajati adalah 0 peserta pelatihan keluarga sehat angkatan VII prosentasenya 0\% dengan klasifikasi tidak pernah, 0 peserta pelatihan keluarga sehat angkatan VII prosentasenya $0 \%$ dengan klasifikasi pernah, 3 peserta pelatihan keluarga sehat angkatan VII prosentasenya $10 \%$ dengan klasifikasi kadang-kadang, 21 peserta pelatihan keluarga sehat angkatan VII prosentasenya $70 \%$ dengan klasifikasi sering, 6 peserta pelatihan keluarga sehat angkatan VII prosentasenya $20 \%$ dengan klasifikasi selalu.

Sesuai dengan penjabaran dapat disimpulkan bahwa motivasi belajar pada pelatihan keluarga sehat angkatan VII tergolong tinggi yaitu dibuktikan sebanyak 21 peserta pelatihan keluarga sehat angkatan VII dengan presentase sebesar $70 \%$ menunjukkan pada klasifikasi sering. Dengan presentase yang tergolong tinggi tersebut, maka dalam hal ini dapat dikatakan bahwa motivasi belajar (X2) berpengaruh terhadap hasil belajar peserta pelatihan keluarga sehat angkatanVII.

Berikut ini adalah post test hasil belajar peserta pelatihan keluarga sehat angkatan VII dengan jumlah soal 40 dan tipe soal adalah pilihan ganda, soal post test sesuai dengan materi pelatihan keluarga sehar.

Berikut ini adalah analisis distribusi dari hasil evaluasi yang telah diolah:

Tabel 4 Hasil Analisis Deskrptif Variabel Hasil Belajar

Description Statistics

\begin{tabular}{lllllll} 
& N & $\begin{array}{l}\text { Minim } \\
\text { um }\end{array}$ & $\begin{array}{l}\text { Maxi } \\
\text { mum }\end{array}$ & $\begin{array}{l}\text { Me } \\
\text { an }\end{array}$ & $\begin{array}{l}\text { Std. } \\
\text { Deviati } \\
\text { on }\end{array}$ & $\begin{array}{l}\text { Var } \\
\text { ianc } \\
\text { e }\end{array}$ \\
\hline $\begin{array}{l}\text { Y Hasil } \\
\text { Belajar }\end{array}$ & 30 & 70 & 95 & $\begin{array}{l}80.5 \\
0\end{array}$ & 6.067 & $\begin{array}{l}36.8 \\
10\end{array}$ \\
\hline $\begin{array}{l}\text { Valid N } \\
\text { (listwise) }\end{array}$ & 30 & & & & & \\
\hline
\end{tabular}

(Sumber: data primer diolah: 2019)

Sesuai dengan hasil jawaban responden pada tabel di atas mengenai variabel hasil belajar (Y) peserta pelatihan keluarga sehat angkatan VII dengan nilai tertinggi 95 dan nilai terendah yang diperoleh peserta pelatihan adalah 70 . Sementara rata-rata nilai yang diperoleh peserta pelatihan adalah 80.50 .

Selanjutnya hasil belajar berupa post test untuk masing-masing responden terkait variabel hasil belajar (Y) dapat dilihat pada tabel kategorisasi sebagai berikut:

Tabel 5 Rentangan Nilai Variabel Hasil Belajar

\begin{tabular}{lll}
\hline Hasil Belajar & $\begin{array}{l}\text { Frekuens } \\
\text { i }\end{array}$ & Prosentase \\
\hline $\begin{array}{l}94-99 \\
\text { (Sangat Tinggi }\end{array}$ & 2 & $6.7 \%$ \\
\hline $\begin{array}{l}88-93 \\
\text { (Tinggi) }\end{array}$ & 1 & $3.3 \%$ \\
\hline $\begin{array}{l}82-87 \\
\text { (Sedang) }\end{array}$ & 9 & $30.0 \%$ \\
\hline $\begin{array}{l}76-81 \\
\text { (Rendah) }\end{array}$ & 14 & $46.7 \%$ \\
\hline
\end{tabular}




\begin{tabular}{lll}
\hline Hasil Belajar & $\begin{array}{l}\text { Frekuens } \\
\text { i }\end{array}$ & Prosentase \\
\hline $70-75$ & 4 & $13.3 \%$ \\
(Sangat & & \\
Rendah) & & \\
\hline Total & 30 & $100 \%$ \\
\hline
\end{tabular}

Berdasarkan tabel 5 tentang hasil belajar diketahui bahwa nilai terbanyak yang diperoleh responden berada pada kisaran nilai 76-81 "rendah" atau 46.7\%, nilai yang sedikit diperoleh responden pada kisaran nilai 88-93 "tinggi" atau $3.3 \%$. Jadi dapat disimpulkan bahwa nilai yang sering muncul yaitu nilai "rendah" dengan kisaran nilai "76-81". Nilai tersebut diperoleh berdasarkan hasil post test yang dilakukan peserta pelatihan keluarga sehat angkatan VII, post test tersebut berisi tentang materi selama kegiatan pelatihan keluarga sehat angkatan VII, yang diujikan kepada peserta pelatihan, untuk mengetahui pengetahuan yang diperoleh peserta pelatihan selama mengikuti kegiatan.

\section{Uji Asumsi Klasik}

\section{Uji Normalitas}

Uji normalitas bertujuan menguji apakah dalam model penelitian variabel terdistribusi secara normal. Uji normalitas data dalam penelitian ini menggunakan pengujian grafik normal PPlot dan OneSample Kolmogorov-Smirnov Test yang terdapat dalam program SPSS 16.0 for Windows. Apabila signifikansi $>0,05$ maka data distribusi normal. Sebaliknya apabila signifikansi $<0,05$ maka data tidak berdistribusi normal.

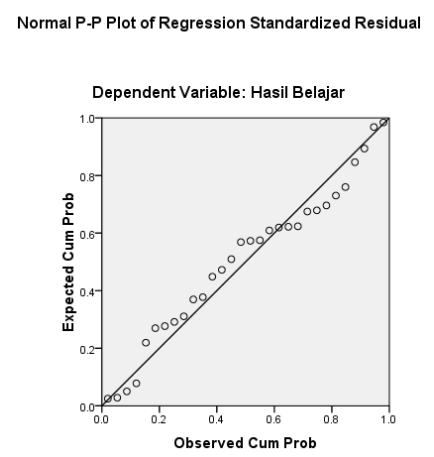

\section{Gambar 1 Uji Normalitas}

Gambar 4.5 terlihat titik-titik berada di sekitar garis diagonal. Titik-titik yang menyebar disekitar garis diagonal menunjukkan residual berdistribusi normal sehingga dapat disimpulkan bahwa residual antara variabel Kompetensi Fasilitator dan Motivasi Belajar terhadap Hasil Belajar berdistribusi normal. Uji normalitas juga dapat dilihat dengan menggunakan uji One Sample Kolmogorov-Smirnov

\begin{tabular}{|c|c|c|c|}
\hline Variabel & $\begin{array}{l}\text { Kolmogor } \\
\text { ov- } \\
\text { Smirnov Z }\end{array}$ & $\begin{array}{l}\text { Asymp } \\
\text {. Sig. } \\
(2- \\
\text { tailed })\end{array}$ & $\begin{array}{l}\text { Keteran } \\
\text { gan }\end{array}$ \\
\hline $\begin{array}{l}\text { Kompete } \\
\text { nsi } \\
\text { Fasilitato } \\
\text { r }\end{array}$ & 0.619 & 0.838 & Normal \\
\hline $\begin{array}{l}\text { Motivasi } \\
\text { belajar }\end{array}$ & 0.893 & 0.402 & Normal \\
\hline $\begin{array}{l}\text { Hasil } \\
\text { Belajar }\end{array}$ & 0.970 & 0.303 & Normal \\
\hline
\end{tabular}

(Sumber: data primer diolah: 2019)

Dari tabel 6, besarnya nilai Kolmogorov-Smirnov Z, pada variabel Kompetensi Fasilitator adalah 0.619 dengan nilai sig 0.838 lebih besar dari 0.05. Kemudian besarnya nilai Kolmogorov-Smirnov Z, pada variabel Motivasi Belajar adalah 0.893 dengan nilai sig 0.402 lebih besar dari 0.05 . Selanjutnya besarnya nilai KolmogorovSmirnov Zpada variabel Hasil Belajar adalah 0.970 dengan nilai sig 0.303 lebih besar dari 0.05 .

\section{Uji Multikolinieritas}

Hasil pengujian asumsi Multikolinieritas menunjukkan di dalam model tidak terjadi Multikolinieritas. Hal ini dapat dilihat dari matriks korelasi antara variabel bebas pada Tabel 4.11

\begin{tabular}{llll}
$\begin{array}{l}\text { Tabel } \\
\text { Multikolinieritas }\end{array}$ & Hasil & Pengujian \\
\hline Variabel & $\begin{array}{l}\text { Toleran } \\
\text { ce }\end{array}$ & VIF & Keterangan \\
\hline Kompeten & 0.776 & 1.28 & Nonmultikolinieri \\
\hline
\end{tabular}




\begin{tabular}{llll}
\hline si & & 9 & tas \\
Fasilitator & & & \\
\hline $\begin{array}{l}\text { Motivasi } \\
\text { Belajar }\end{array}$ & 0.776 & 1.28 & $\begin{array}{l}\text { Nonmultikolinieri } \\
\text { tas }\end{array}$ \\
\hline
\end{tabular}

(Sumber: Data primer diolah: 2019)

Pengujian multikolinieritas dapat diketahui dengan melihat VIF dan nilai tolerance yang diperoleh. Jika nilai-nilai toleransi lebih besar dari 0,10 dan nilai VIF lebih kecil dari 10 maka dapat disimpulkan tidak terjadi multikolinieritas. Dari hasil pengujian diketahui bahwa seluruh nilai VIF pada variabel Kompetensi Fasilitator dan Motivasi Belajar lebih kecil dari 10 dan nilai tolerance lebih besar dari 0,10 sehingga disimpulkan bahwa terjadi multikolinieritas.

\section{Uji Heteroskedastisitas}

Uji heteroskedastisitas dilakukan untuk menguji apakah dalam model regresi terjadi ketidaksamaan variasi dari residual suatu pengamatan ke pengamatan yang lain. Model regresi yang baik adalah yang homokedastisitas atau tidak heterokedastisitas. Uji heterokesdaksitas dalam penelitian ini diuji dengan scatterplot. Data tidak mengalami heteroskedastisitas apabila dalam gambar scatterplot titik-titik tersebut di atas dan di bawah angka nol dan tidak membentuk pola tertentu yang teratur. Uji Heteroskedastisitas pada Kompetensi Fasilitator dan Motivasi Belajar terhadap Hasil Belajar dapat dilihat pada tabel dibawah ini.

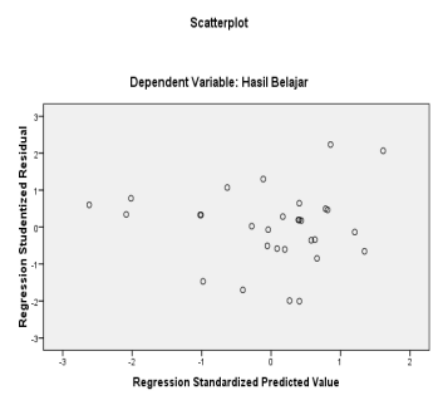

\section{Gambar 2 Uji Heteroskedastisitas}

Hasil uji heteroskedastisitas variabel Kompetensi Fasilitator dan Motivasi Belajar terhadap Hasil Belajar menunjukkan bahwa titik-titik tersebut di atas dan di bawah angka nol. Titik-titik menyebut dan tidak membentuk pola tertentu yang teratur sehingga dapat disimpulkan bahwa dalam model regresi tidak terjadi heteroskedastisitas.

\section{Analisis Regresi Berganda}

Analisis regresi berganda ditujukan untuk mengetahui pengaruh atau hubungan variabel bebas kompetensi fasilitator (X1) dan Motivasi Belajar (X2) serta variabel terikat hasil belajar (Y), maka untuk memperoleh hasil yang lebih akurat, penulis menggunakan bantuan program software SPSS versi 16.0 for windows.

Berdasarkan hasil analisis regresi linier berganda diperoleh nilai B konstan sebesar 51.918. Nilai B pada variabel penggunaan kompetensi fasilitator (X1) sebesar -0.157. Nilai B pada variabel motivasi belajar (X2) sebesar 0.459 . Sehingga hasil tersebut dapat diuraikan sebagai berikut:

1. Pengaruh kompetensi fasilitator terhadap hasil belajar berdasarkan hasil analisis regresi berganda dihasilkan B sebesar -0.157 dan nilai signifikan 0.044 maka nilai tersebut dapat disimpulkan $\mathrm{H}_{0}$ ditolak dan $\mathrm{H}_{1}$ diterima, sehingga dapat disimpulkan terdapat pengaruh positif secara signifikan antara kompetensi fasilitator terhadap hasil belajar peserta pelatihan Keluarga Sehat Angkatan VII di UPT Pelatihan Kesehatan Masyarakat Murnajati.

2. Pengaruh motivasi belajar terhadap hasil belajar berdasarkan hasil analisis regresi berganda dihasilkan B sebesar 0.459 dan nilai signifikan 0.009 maka nilai tersebut dapat disimpulkan $\mathrm{H}_{0}$ ditolak dan $\mathrm{H}_{2}$ diterima, sehingga dapat disimpulkan terdapat pengaruh positif secara signifikan antara motivasi belajar terhadap hasil belajar peserta pelatihan Keluarga Sehat Angkatan VII di UPT Pelatihan Kesehatan Masyarakat Murnajati.

\section{Uji Hipotesis}

Pengujian hipotesis bertujuan untuk membuktikan hipotesis yang diajukan 
apakah diterima atau ditolak. Uji hipotesis dalam penelitian ini terdiri dari uji t dan uji F yang dilakukan untuk mengetahui pengaruh variabel kompetensi fasilitator (X1) dan motivasi belajar (X2) terhadap variable terikat hasil belajar (Y) baik secara parsial maupun secara simultasn. Proses analisis dilakukan sengan bantuan komputer statistik yaitu program SPSS 16.0 for windows dengan model analisis regresi ganda.

\section{Uji t}

Uji t digunakan untuk mengetahui apakah variabel-variabel independen secara parsial yang berpengaruh nyata atau tidak terhadap variabel dependen, derajat signifikansi yang digunakan adalah 0,05. Apabila nilai signifikansi lebih kecil dari derajat kepercayaan maka kita menerima $\mathrm{H}_{1}, \mathrm{H}_{2}, \mathrm{H}_{3}$ yang menyatakan bahwa suatu variabel indepen secara parsial mempengaruhi variabel dependen.

Menurut kriteria pengujian:

$\mathrm{H}_{1}, \mathrm{H}_{2}, \mathrm{H}_{3}$ diterima apabila $\mathrm{t}_{\text {hitung }}>\mathrm{t}_{\text {tabel }}$ (2.052)

$\mathrm{H}_{1}, \mathrm{H}_{2}, \mathrm{H}_{3}$ ditolak apabila $\mathrm{t}_{\text {hitung }}<\mathrm{t}_{\text {tabel }}$ (2.052)

Uji statistic t-test (parsial) menunjukkan pengaruh kompetensi fasilitator (X1) dan motivasi belajar (X2) terhadap hasil belajar (Y) adalah berpengaruh secara parsial. Berdasarkan tabel di atas, maka dapat dideskripsikan sebagai berikut, yaitu:

1. Variabel Kompetensi Fasilitator (X1) memiliki nilai signifikansi (Sig.) 0.044 pada tabel Coefficients ${ }^{\mathrm{a}}$ dengan nilai $\alpha$ (derajat signifikansi) 0.05 artinya $0.044<0.05$ atau terdapat pengaruh yang signifikan dan uji t menunjukkan 2.112> $t_{\text {tabel }}$ (2.052). Maka dapat disimpulkan bahwa $\mathrm{H}_{1}$ diterima dan $\mathrm{H}_{\mathrm{O}}$ ditolak.

2. Variabel Kompetensi Fasilitator (X1) memiliki nilai signifikansi (Sig.) 0.009 pada tabel Coefficients ${ }^{\mathrm{a}}$ dengan nilai $\alpha$ (derajat signifikansi) 0.05 artinya $0.009<0.05$ atau terdapat pengaruh yang signifikan dan uji t menunjukkan 2.817> $t_{\text {tabel }}$ (2.052). Maka dapat disimpulkan bahwa $\mathrm{H}_{2}$ diterima dan $\mathrm{H}_{\mathrm{O}}$ ditolak.

\section{Uji F}

Uji $F$ digunakan untuk menguji variabel-variabel bebas secara bersamasama terhadap variabel terikat. Pada penelitian ini variabel bebas (kompetensi fasilitator dan motivasi belajar) sedangkan variabel terikat (hasil belajar peserta pelatihan keluarga sehat angkatan VII).

nilai signifikansi sebesar $0.028^{\mathrm{a}}<0.05$, dengan demikian dapat disimpulkan bahwa $\mathrm{H}_{0}$ ditolak, yang berarti "kompetensi fasilitator, motivasi belajar" berpengaruh secara simultan terhadap hasil belajar peserta pelatihan keluarga sehat angkatan VII di UPT Pelatihan Kesehatan Masyarakat murnajati.

\section{PEMBAHASAN}

\section{Pengaruh Kompetensi Fasilitator Terhadap Hasil Belajar Peserta Pelatihan Keluarga Sehat Angkatan VII}

Kompetensi yang dimiliki oleh seorang fasilitator akan sangat membantu para peserta pelatihan untuk memperoleh hasil belajar yang maksimal. Tanpa adanya kompetensi yang baik dari seorang fasilitator, akan menghambat semangat peserta pelatihan dalam belajar karena fasilitatornya tidak mampu memahami keadaan dan kondisi peserta pelatihan sehingga terkadang peserta pelatihannya kurang semangat dalam mengikuti proses pembelajaran. Peraturan Menteri Pendidikan Nasional No. 16 Tahun 2007 menjelaskan bahwa "setiap pendidik wajib memenuhi standar kualifikasi akademik dan kompetensi pendidik sesui dengan peraturan pendidikan nasional." Standar kompetensi pendidik yang harus dipenuhi oleh pendidik ada empat kompetensi, yaitu (a) kompetensi pedagogic, (b) kompetensi kepribadian, (c) kompetensi sosial, (d) kompetensi profesional.

Kompetensi merupakan merupakan keahlian, kecakapan dasar pendidik yang harus dikuasai dalam melaksanakan tugasnya sebagai fasilitator. Seorang fasilitator harus menguasai keahlian dan 
ketrampilan teoritik dan praktik dalam proses ppembelajaran serta mengaplikasikan secara nyata ketika proses pembelajaran ini berlangsung. Menurut Dimyati dan Mudjiono (2006:34) "hasil belajar adalah hasil dari suatu interaksi tindakan belajar mengajar." Hasil belajar adalah suatu pencapaian peserta didik dari kegiatan belajarnya dan diperoleh dari proses penilaian hasil belajar dan evaluasi yang dilaksanakan pada waktu tertentu. Pencapaian suatu tujuan belajar di dalam kegiatan atau proses belajar pembelajaran hasilnya akan diukur melalui hasil belajar tersebut. Berhasil tidaknya peserta didik di dalam melaksanakan kegiatan belajar dapat diketahui dari hasil belajar tersebut atau prestasi belajarnya.

Berdasarkan hasil pennelitian menunjukkan bahwa variabel Kompetensi Fasilitator (X1) memiliki nilai signifikansi (Sig.) 0.044 pada tabel Coefficients ${ }^{\mathrm{a}}$ dengan nilai $\alpha$ (derajat signifikansi) 0.05 artinya $0.044<0.05$ atau terdapat pengaruh yang signifikan dan uji $\mathrm{t}$ menunjukkan 2.112> $\mathrm{t}_{\text {tabel }}$ (2.052). Artinya kompetensi fasilitator berpengaruh signifikan terhadap hasil belajar

\section{Pengaruh Motivasi Belajar Terhadap Hasil Belajar Peserta Pelatihan Keluarga Sehat Angkatan VII}

Pencapaian hasil belajar yang maksimal tidak hanya dengan adanya intelegensi atau kecerdasan yang ada pada tiap peserta pelatihan. Dalam proses belajar haruslah diperhatikan apa yang dapat mendorong peserta didik agar dapat belajar dengan baik. seluruh daya kekuatan untuk mendorong peserta didik agar belajar itu disebut dengan motivasi belajar.

Salah satu bentuk keseriusan dalam belajar adalah adanya motivasi peserta didik pada saat mengikuti proses belajaar mengajar. Motivasi merupakan salah satu faktor yang penting bagi peserta didik agar dapat memahami materi yang disampaikan oleh fasilitator di depan kelas. Motivasi ini dapat tumbuh akibat adanya dorongan yang berasal dari dalam dirinya untuk belajar sungguh-sungguh. Disamping itu, motivasi peserta didik juga berasal dari luar diri peserta didik, seperti halnya motivasi dari fasilitator, keluarga atau temannya. Menurut Sardiman (2007:75) motivasi adalah "keseluruhan daya penggerak di dalam diri peserta didik yang menimbulkan kegiatan belajar, yang menjamin kelangsungan dari kegiatan belajar, yang menjamin kelangsungan dari kegiatan belajar dan yang memberikan arah pada kegiatan belajar, sehingga tujuan yang dikehendaki oleh subjek belajar itu dapat tercapai." Peserta didik yang memiliki motivasi motivasi kuat, akan mempunyai banyak energy untuk melakukan kegiatan belajar. Begitu pula, seorang peserta didik yang memiliki intelegensi cukup tinggi, gagal karena kekurangan motivasi.

Berdasarkan hasil penelitian menunjukkan bahwa variabel motivasi belajar (X2) memiliki nilai signifikansi (Sig.) 0.009 pada tabel Coefficients ${ }^{\mathrm{a}}$ dengan nilai $\alpha$ (derajat signifikansi) 0.05 artinya $0.009<0.05$ atau terdapat pengaruh yang signifikan dari uji t menunjukkan 2.817> $\mathrm{t}_{\text {tabel }}$ (2.052). Artinya Motivasi Belajar berpengaruh signifikan terhadap Hasil Belajar.

\section{Pengaruh Kompetensi Fasilitor dan Motivasi Belajar Terhadap Hasil Belajar Peserta Pelatihan Keluarga Sehat Angkatan VII}

Kompetensi fasilitator ini merupakan suatu hal yang mutlak yang harus dimiliki oleh seorang fasilitator, dan kompetensi fasilitator tersebut tidak serta merta didapatkan begitu saja, tapi harus ada usaha yang keras untuk memperolehnya. Pada akhirnya kompetensi fasilitator ini merupakan tolak ukur untuk menentukan kualitas fasilitator tersebut. Fasilitator sebagai pendidik profesional dan merupakan unsur yang paling dominan dalam mewujudkan pendidikan yang berkualitas dituntut untuk memiliki kompetensi-kompetensi agar dapat 
melaksanakan tugasnya dengan baik. Undang-Undang No. 14 Tahun 2005 tentang guru dan dosen menjelaskan bahwa secara umum pendidik adalah "pendidik profesional dengan tugas utama mendidik, mengajar, membimbing, mengarahkan, melatih, menilai, dan mengevaluasi peserta didik pada pendidikan anak usia dini jalur pendidikan formal, pendidikan dasar dan pendidikan menengah." Sebagai fasilitator, tugas pendidik yang paling utama adalah " $t o$ facilitate of learning" (memberi kemudahan belajar), bukan hanya menceramahi, atau mengajar, apalagi menghajar peserta didik, kita perlu pendidik yang demokratis, jujur dan terbuka, serta siap dikritik oleh peserta didiknya. Untuk kepentingan tersebut, pendidik merupakan faktor penting yang besar pengaruhnya terhadap keberhasilan pembelajaran, bahkan sangat menentukan berhasil tidaknya peserta didik belajar.

Motivasi belajar merupakan salah satu aspek psikis yang membantu dan mendorong seseorang untuk mencapai tujuannya. Maka motivasi harus ada dalam diri seseorang, sebab motivasi merupakan modal dasar untuk mencapai tujuan. Dengan demikian, motivasi harus menjadi pangkal permulaan dari pada semua aktivitas.

Berdasarkan hasil penelitian menunjukkan bahwa Kompetensi Fasilitator memiliki nilai signifikansi (Sig.) 0.044 pada tabel Coefficients ${ }^{\mathrm{a}}$ dengan nilai $\alpha$ (derajat signifikansi) 0.05 artinya $0.044<0.05$ atau terdapat pengaruh yang signifikan dan uji $\mathrm{t}$ menunjukkan 2.112> $\mathrm{t}_{\text {tabel }}$ (2.052). Artinya Kompetensi Fasilitator berpengaruh signifikan terhadap hasil belajar, dan pada Motivasi Belajar memiliki nilai signifikansi (Sig.) 0.009 pada tabel Coefficients ${ }^{\mathrm{a}}$ dengan nilai $\alpha$ (derajat signifikansi) 0.05 artinya $0.009<0.05$ atau terdapat pengaruh yang signifikan dari uji t menunjukkan 2.817> $t_{\text {tabel (2.052). Artinya Motivasi Belajar }}$ berpengaruh signifikan terhadap Hasil Belajar. Dengan demikian dapat disimpulkan bahwa secara simultan variabel Kompetensi Fasilitator dan variabel Motivasi Belajar memiliki pengaruh positif dan signifikan terhadap Hasil Belajar.

\section{PENUTUP}

\section{A. Kesimpulan}

Berdasarkan hasil penelitian dan pembahasan maka berikut adalah kesimpulan yang penulis ambil dalam penelitian ini.

Secara parsial terdapat pengaruh yang signifikan antara variabel kompetensi fasilitator (X1) dan motivasi belajar (X2) terhadap hasil belajar peserta pelatihan keluarga sehat angkatan VII di UPT Pelatihan Kesehatan Masyarakat Murnajati.

Secara simultan variabel bebas yang terdiri dari kompetensi fasilitator (X1) dan motivasi belajar (X2) berpengaruh signifikan terhadap hasil belajar peserta pelatihan keluarga sehat angkatan VII di UPT Pelatihan Kesehatan Masyarakat Murnajati.

Pengaruh kompetensi fasilittaor dan motivasi belajar terhadap hasil belajar peserta pelatihan keluarga sehat angkatan VII di UPT Pelatihan Kesehatan Masyarakat Murnajati, yang paling dominasi yaitu dipengaruhi oleh motivasi belajar yaitu dibuktikan dengan tingginya rata-rata yang dicapai.

\section{B. Saran}

Berdasarkan kesimpulan, berikut adalah saran yang dapat peneliti berikan:

Bagi lembaga dari hasil kesimpulan yang menunjukkan adanya pengaruh positif dan signifikan antara variabel kompetensi fasilitator (X1) terhadap hasil belajar peserta pelatihan keluarga sehat angkatan VII di UPT Pelatihan Kesehatan Masyarakat Murnajati. Disarankan untuk fasilitator dan yang memegang peran di lembaga untuk bisa meningkatkan dan mempertahankan komepetensi fasilitator yang baik untuk mencapai hasil belajar peserta pelatihan yang lebih baik lagi. 
Adanya pengaruh posistif dan signifikan antara variabel motivasi belajar (X2) terhadap hasil belajar peserta pelatihan keluarga sehat angkatan VII, peserta pelatihan disarankan untuk memperhatikan dan mencoba menumbuhkan motivasi belajar yang tinggi dan stabil demi tercapainya hasil belajar yang maksimal sesuai dengan tujuan pelatihan, disarankan untuk meningkatkan kesadaran dan kemampuan peserta pelatihan terhadap kompetensinya.

Bagi Peneliti selanjutnya yang ingin mengkaji lebih lanjut tentang hasil belajar dapat lebih mengembangkan terkait dengan kompetensi fasilitator dan motivasi belajar secara rinci seperti faktor-faktor yang mempengaruhi terhadap kompetensi fasilitator dan motivasi belajar yang selanjutnya bisa meningkatkan kualitas keduanya sehingga tercapai hasil belajar yang maksimal.

\section{DAFTAR RUJUKAN}

Anwar, Muhammad. 2018. Menjadi Guru Profesional. Jakarta: Prenadamedia Group.

Emda, Amna. 2017. Kedudukan Motivasi Belajar Siswa Dalam

Pembelajaran. Lantanida Journal, 2 (5), $93^{-}$196. Dari http://jurnal.arraniry.ac.id/index.php/lantanida/art icle/download/2838/2064.

Kamil, Mustofa. 2012. Model Pendidikan dan Pelatihan (Konsep dan Aplikasi). Bandung: Alfabeta.

Marzuki, Saleh. 2012. Pendidikan Non Formal: Dimensi dalam Keaksaraan Fungsional, Pelatihan, dan Andragogi. Bandung: PT Remaja Rosdakarya.

Noe, RA \& Tews, Mj. 2017. Human Resource Management Reviev: Does Training Have To Be Fun? A Review and Conceptual Model of The Role of Fun In Workplace Training, 29 (2), $226^{-} 233$.
Dari

https://doi.org/10.1016/j.hrmr.2017 .11.003.

Sugiyono. 2016. Metode Penelitian Kuantitatif, Kualitatif, dan R\&D. Bandung: Alfabeta.

Suharsimi, Arikunto. Prosedur Penelitian Suatu Pendekatan Praktik. 2014. Jakarta: Rineka Cipta.

Sugiyono. 2016. Statistika Untuk penelitian. Bandung: Alfabeta.

Sudjana, Nana. 2009. Penilaian Hasil Belajar Mengajar. Jakarta: PT Bumi Aksara.

Sardiman. 2007. Interkasi dan Motivasi Belajar Mengajar. Jakarta: PT Raja Grafindo Persada.

Undang-Undang Republik Indonesia Nomor 20 Tahun 2003 Tentang SISDIKNAS \& Peraturan Pemerintah Tahun 2010 Tentang Penyelenggaraan Pendidikan Serta Wajib Belajar. Bandung: Citra Umbara.

Winarno, Agung. 2014. Pengantar Pendidikan. Malang: Universitas Negeri Malang.

Mulyasa, E. 2015. Menjadi Guru Profesional: Menciptakan Pembelajaran Kreatif dan Menyenangkan. Bandung: PT Remaja Rosdakarya Offset.

Rusman. 2017. Belajar dan Pembelajaran Berorientasi Standar Proses Pendidikan. Jakarta: Kencana.

Zunaidi, Anang. 2017. Pengaruh Fasilitas Belajar dan Motivasi Belajar Terhadap Hasil Belajar Siswa Pada Mata Pelajaran Ekonomi Kelas XI IPS MA An Nur Bululawang. Skripsi tidak diterbitkan. Universitas Negeri Malang.

Peraturan

Menteri Pendidikan dan Kebudayaan No 20 Tahun 2003, tentang Standar Pendidikan Sistem Pendidikan 
Nasional pasal 1. Bandung: Citra

Umbara.

Peraturan Menteri Pendidikan dan

Kebudayaan No. 19 Tahun 2005,

tentang Standar Pendidikan

Sistem Pendidikan Nasional pasal

6 ayat 3 . Bandung: Citra Umbara. 